\title{
Changes in expression of insulin signaling pathway genes by dietary fat source in growing-finishing pigs
}

Seung-Chang Kim, Hong-Chul Jang ${ }^{1}$, Sung-Dae Lee², Hyun-Jung Jung², Jun-Cheol Park², Seung-Hwan Lee, Tae-Hun Kim ${ }^{1}$ and Bong-Hwan Choi ${ }^{1^{*}}$

\begin{abstract}
This study investigated changes in gene expression by dietary fat source, i.e., beef tallow, soybean oil, olive oil, and coconut oil (each $3 \%$ in feed), in both male and female growing-finishing pigs. Real-time PCR was conducted on seven genes (insulin receptor; INSR, insulin receptor substrate; IRS, phosphatidylinositol (3,4,5)-triphosphate; PIP3, 3-phosphoinositide-dependent protein kinase-1; PDK1, protein kinase B; Akt, forkhead box protein O1; FOXO1 and cGMP-inhibited 3', 5'-cyclic phosphodiesterase; PDE3) located upstream of the insulin signaling pathway in the longissimus dorsi muscle (LM) of pigs. The INSR, IRS, PIP3, and PDE3 genes showed significantly differential expression in barrow pigs. Expression of the PIP3 and FOXO1 genes was significantly different among the four dietary groups in gilt pigs. In particular, the PIP3 gene showed the opposite expression pattern between barrow and gilt pigs. These results show that dietary fat source affected patterns of gene expression according to animal gender. Further, the results indicate that the type of dietary fat affects insulin signaling-related gene expression in the LM of pigs. These results can be applied to livestock production by promoting the use of discriminatory feed supplies.
\end{abstract}

Keywords: Dietary fat, Gene expression, Growing-finishing pig, Insulin signaling pathway

\section{Background}

Fat supplementation with high energy value is important for growing-finishing pigs. Addition of dietary fat has been shown to improve feed efficiency during the post-weaning period [1-5]. Dietary fat type affects fatty acid composition in the LM [6]. Intramuscular fat (IMF) deposition and back fat thickness (BF) are the most important candidate traits for understanding the interactions between nutrition and gene expression in pigs [7].

The insulin signaling pathway has a well established relationship with fat metabolism. Therefore, genes related to the insulin signaling pathway have long been the subject of major research. Insulin is the major hormone for fatty acid synthesis, glycolysis, and glycogenesis, and it suppresses $\beta$-oxidation, gluconeogenesis, glycogenolysis, and apoptosis by controlling critical energy functions such as

\footnotetext{
* Correspondence: bhchoi@korea.kr

'Animal Genomics \& Bioinformatics Division, National Institute of Animal Science, Rural Development Administration, Chuksan-gil 77, Kwonsun-gu, Suwon, Korea

Full list of author information is available at the end of the article
}

glucose and lipid metabolism [8-10]. Insulin activates insulin receptor (IR), which is a tyrosine kinase that phosphorylates and recruits different substrate adaptors such as the IRS family of proteins. Phosphorylated IRS then displays binding sites for numerous signaling partners. Among them, PI3K plays a major role in insulin function, mainly via activation of the Akt/PKB pathway. Activated Akt induces anti-lipolysis through activation of PDE3 as well as regulates gluconeogenesis and glycogenolysis through inhibition of forkhead box protein O1 (FOXO1). Activation of PDE3 decreases the concentration of cAMP, which in turn reduces protein kinase A (PKA) activity [11]. PKA is responsible for activation of lipase, which induces lipolysis as well as other physiological pathways [12]. Inhibition of FOXO1 decreases transcription of glucose 6-phosphates, which consequently reduces rates of gluconeogenesis and glycogenolysis [13]. Protein phosphorylation is controlled by the opposing and coordinated activities of protein kinases and phosphatases catalyzing protein phosphorylation and dephosphorylation, respectively [14]. This reversible phosphorylation of proteins is a 
major mechanism responsible for the regulation of cellular functions, including metabolism, signal transduction, cell division, and memory [15].

The Akt/PI3K signaling pathway is crucial to cell growth and survival. As such, current research has attempted to develop anti-cancer drugs based on the Akt/PI3K signaling pathway. Further, many studies have focused on mechanisms related to glucose uptake via Glut4 as well as protein synthesis via mTOR in the insulin signaling pathway. However, little is known about other pathway mechanisms. In this study, we investigated genes located upstream of the insulin signaling pathway related to glycolysis and anti-lipolysis in growing-finishing pigs.

\section{Methods}

\section{Animals and diets}

A total of 72 crossbred pigs (Landrace $\times$ Large White $\times$ Duroc) consisting of 36 gilt and barrow pigs each were used. The animals had an average body weight of $71 \pm$ $1 \mathrm{~kg}$, were about 130 days of age, and were divided according to gender. The pigs were randomly allocated into 24 pens $(320 \times 150 \mathrm{~cm}$ with solid concrete flooring) in a confined pig house, with three pigs per pen and six replicate pens per treatment. Treatment groups consisted of the same numbers of gilts and barrows. Each pen was equipped with a nipple water bottle and a stainless steel feeder, and pigs were given free access to feed and water throughout. Animals received care in accordance with the standard guideline for the Care and Use of Laboratory Animals provided by the National Institute of Animal Science Animal Care Committee, and the experiment was conducted with approval from the animal ethics committee and Operation rule of animal experiment ethics in the National Institute of Animal Science (approval number: 2009-076).

The ingredients and chemical compositions of the growing and finishing diets used in this experiment are shown in Table 1. All other nutrient requirements met or exceeded NRC recommendations for growing and finishing pigs (NRC, 1998). Dietary fat sources used in the present study were beef tallow, coconut oil, olive oil, and soybean oil, which were added to feed at a concentration of $3.0 \%$. For this, fat sources were melted at approximately $50^{\circ} \mathrm{C}$, after which they were diluted to approximately $10 \%$. The $10 \%$ fat diets were then formulated to $3.0 \%$ fat diets. Growing diet was administered to crossbred pigs for an experimental period of $14 \pm 3$ days, whereas finishing diet was administered to crossbred pigs for an experimental period of $28 \pm 3$ days.

\section{Slaughtering and sampling}

Pigs with a live weight of $102 \pm 3 \mathrm{~kg}$ were transported to a standard abattoir near the experimental station. The
Table 1 Composition of experiment diets, as-fed basis

\begin{tabular}{lcc}
\hline Items & Growing & Finishing \\
\hline Ingredients, \% & & \\
Corn grain & 62.38 & 57.64 \\
Soybean meal & 22.00 & 14.00 \\
Wheat & 10.00 & 11.00 \\
Wheat bran & 0.00 & 12.00 \\
Fat source ${ }^{1)}$ & 3.00 & 3.00 \\
L-lysine & 0.06 & 0.06 \\
Limestone & 0.65 & 1.10 \\
Tricalcium phosphate & 1.11 & 0.30 \\
Sodium chloride & 0.30 & 0.30 \\
Vitamin + mineral premix ${ }^{2)}$ & 0.40 & 0.40 \\
Antibiotics & 0.10 & 0.00 \\
Chemical composition ${ }^{3)}$ & & \\
DE, kcal/kg & 3,500 & 3,400 \\
Crude protein, \% & 15.44 & 13.42 \\
Crude fat, \% & 5.50 & 5.67 \\
Crude fiber, \% & 3.45 & 3.94 \\
Lysine,\% & 0.82 & 0.66 \\
Methionine + (ystine, \% & 0.52 & 0.47 \\
Calcium, \% & 0.69 & 0.60 \\
Phosphorus, \% & 0.54 & 0.47 \\
\hline Fat soure : Bef talow, soybean &
\end{tabular}

${ }^{1)}$ Fat source : Beef tallow, soybean oil, olive oil, coconut oil.

${ }^{2)}$ Vitamin and mineral contents per kilogram of diet provided by premix: Vitamin A, 2,000,000 IU; Vitamin $D_{3}, 400,000$ IU; Vitamin E, 2,500 IU; Vitamin $\mathrm{K}_{3}$, $100 \mathrm{mg}$; Vitamin $\mathrm{B}_{1}, 100 \mathrm{mg}$; Vitamin $\mathrm{B}_{2}, 300 \mathrm{mg}$; Vitamin $\mathrm{B}_{12}, 1,200 \mathrm{mcg}$; Niacin, 2,000 mg; d-Pantothenicalcium, 1,000 mg; Folic acid, $200 \mathrm{mg}$; Biotin, 20 mg; Choline chloride, 25,000 mg; Mn, 12,000 mg; Zn, 15,000 mg; Fe 4,000 mg; Cu, 500 mg; I, 250 mg; Co, 100 mg; Mg, 2,000 mg; B.H.T., 5,00 mg. ${ }^{3)} \mathrm{Chemical}$ composition was calculated from ingredient proportion.

pigs were then slaughtered at $12 \mathrm{~h}$ after feed restriction. Briefly, pigs were stunned electrically ( $300 \mathrm{~V}$ for $3 \mathrm{~s}$ ) with a pair of stunning tongs, shackled by the right leg, and exsanguinated while hanging. The carcasses were placed in a dehairer at $62^{\circ} \mathrm{C}$ for $5 \mathrm{~min}$, and remaining hair was removed using a knife and flame. The carcasses were eviscerated and split before being placed in a chiller set at $4^{\circ} \mathrm{C}$ for $12 \mathrm{~h}$. Immediately, 24 LM samples were taken from animals in the four dietary groups, frozen in liquid nitrogen, and stored at $-80^{\circ} \mathrm{C}$ until preparation of total RNA.

\section{RNA isolation and CDNA synthesis}

The tissue was powdered with liquid nitrogen, and total RNA was extracted from $10 \mathrm{mg}$ of muscle tissue using $1 \mathrm{~mL}$ of TRIzol $^{\circ}$ reagent (Invitrogen, Inc., USA). RNA quality was confirmed by examining $28 \mathrm{~S}$ and $18 \mathrm{~S}$ rRNA bands on $1.5 \%$ agarose gels stained with ethidium bromide. Total RNA was purified from all samples using an RNeasy MinElute cleanup kit (Qiagen, USA). 
Complementary DNA (cDNA) synthesis was performed by reverse transcription using SuperScript ${ }^{\mathrm{TM}}$ II reverse transcriptase (Invitrogen, USA) as follows. Aliquots $(4 \mu \mathrm{L})$ of total RNA were preincubated with $50 \mathrm{ng}(1 \mu \mathrm{L})$ of random primer mix (Promega, USA) and $2.5 \mathrm{mM}(1 \mu \mathrm{L}) \mathrm{dNTP} \operatorname{mix}$ at $65^{\circ} \mathrm{C}$ for $5 \mathrm{~min}$. The tubes were placed on ice, after which $4 \mu \mathrm{L}$ of $5 \times$ first-stand buffer $(250 \mathrm{mM}$ Tris- $\mathrm{HCl}, \mathrm{pH}$ 8.3, $375 \mathrm{mM} \mathrm{KCl}$, $\left.15 \mathrm{mM} \mathrm{MgCl}_{2}\right), 2 \mu \mathrm{L}$ of $0.1 \mathrm{M} \mathrm{DTT}$, and 40 units $(0.5 \mu \mathrm{L})$ of RNase inhibitor (Promega, USA) were added, followed by incubation at $42^{\circ} \mathrm{C}$ for $2 \mathrm{~min}$. After addition of 200 units $(1 \mu \mathrm{L})$ of SuperScript ${ }^{\mathrm{TM}}$ II reverse transcriptase (Invitrogen, USA), incubation was continued at $42^{\circ} \mathrm{C}$ for $50 \mathrm{~min}$. Reverse transcriptase activity was terminated by incubation at $70^{\circ} \mathrm{C}$ for $15 \mathrm{~min}$. The resulting cDNA was stored at $-20^{\circ} \mathrm{C}$ until used in quantitative real-time PCR (qRT-PCR).

\section{Quantitative real-time polymerase chain reaction (qRT- PCR) analysis}

To validate the seven differentially expressed genes (DEGs) related to insulin signaling based on the KEGG database in the LM of pigs, we performed qRT-PCR using Power SYBR Green PCR Master Mix (Applied Biosystems, USA) and the ABI 7500 Real-Time PCR system (Applied Biosystems USA). All primer sets were designed using the Primer3 program (http://bioinfo.ut.ee/ primer3-0.4.0/) to amplify products ranging from 100 to 200 base pairs (Table 2). The $\beta$-actin gene (GenBank Acc. No. AY550069) was used as an internal control. qRT-PCR was performed in a total volume of $20 \mu \mathrm{L}$ containing $2 \mu \mathrm{L}$ of $\mathrm{cDNA}(0.1 \mu \mathrm{g} / \mu \mathrm{L}), 10 \mu \mathrm{L}$ of $2 \times \mathrm{SYBR}^{\circ}$ Green PCR Master Mix (Applied Biosystems, USA), and
$1 \mu \mathrm{L}$ each of $10 \mathrm{pM}$ forward and reverse primers. The amplification reaction was initiated by incubation for $2 \mathrm{~min}$ at $50^{\circ} \mathrm{C}$, followed by 40 cycles of $95^{\circ} \mathrm{C}$ for $10 \mathrm{~min}$, $95^{\circ} \mathrm{C}$ for $10 \mathrm{~s}$, and $60^{\circ} \mathrm{C}$ for $1 \mathrm{~min}$. After 36 cycles, a final extension step was performed at $72^{\circ} \mathrm{C}$ for $1 \mathrm{~min}$. qRTPCR for each gene was repeated three times. Following amplification, melting curve analysis was performed to verify the specificity of the reactions. The endpoint used in real-time RT-PCR quantification (Ct) was defined as the PCR threshold cycle number. The $\Delta C$ t value was determined by subtracting the $\beta$-actin $\mathrm{Ct}$ value for each sample from the target $\mathrm{Ct}$ value. Finally, we transformed the expression level to the $2^{-\Delta C t}$ value for further analysis.

\section{Statistical analysis}

To identify DEGs among the dietary fat groups, statistical analysis was performed by analysis of variance (ANOVA) using the MIXED procedure with the $\mathrm{R}$ statistical package (http://www.R-project.org) for animals nested within age as the random effect. We also examined the least square means (LSM) to test the significance of differences among the groups using Duncan's multiple range test. The following statistical model was used to estimate the effects of dietary fat type on individual gene expression:

$$
Y_{i j}=\mu+F E D_{i}+D A Y_{j}+e_{i j}
$$

Where $Y_{i j}$ is the target gene intensity $\left(2^{-\Delta C t}\right), \mu$ is the overall mean, $F E D_{i}$ is the fixed effect of the $i$ th dietary type, and $D A Y_{j}$ is animals nested within age as a random effect.

Table 2 List of insulin signaling pathway primers for qPCR

\begin{tabular}{|c|c|c|}
\hline Gene Symbol & Primer sequences Forward / Reverse & Product Size (bp) \\
\hline \multirow[t]{2}{*}{ INSR } & F:5'-TTCACTGGCAATCGCATTGAGCTG-3' & $137 \mathrm{bp}$ \\
\hline & R:5'-TCATGGGTCACAGGGCCAATGATA-3' & \\
\hline \multirow[t]{2}{*}{ IRS } & F:5'-AGGAAGTTTGGCAGGTGATCCTGA-3' & $200 \mathrm{bp}$ \\
\hline & R:5'-ACGGCCCACTTCGATGAAGAAGAA-3' & \\
\hline \multirow[t]{2}{*}{ PIP3 } & F:5'-CTITGCAGAGCTTGACCCAGAT-3' & $100 \mathrm{bp}$ \\
\hline & R:5'-GAGCTTGTGGGCTTGCCTTCATTT-3' & \\
\hline \multirow[t]{2}{*}{ PDK1 } & F:5'-GGAAACCCTTGGCACCAGTTTGTA-3' & $183 \mathrm{bp}$ \\
\hline & R:5'-TCGGAGTTCTTGTGACCACGGAAT-3' & \\
\hline \multirow[t]{2}{*}{ Akt } & F:5'-AGAAGCTCTTCGAGCTCATCCTCA-3' & $148 \mathrm{bp}$ \\
\hline & R:5'-TGCATGATCTCCTTGGCATCCTCA-3' & \\
\hline \multirow[t]{2}{*}{ FOXO1 } & F:5'-TCCCACACAGTGTCAAGACAACGA-3' & $118 \mathrm{bp}$ \\
\hline & R:5'-ACTGCTTCTCTCAGTTCCTGCTGT-3' & \\
\hline \multirow[t]{2}{*}{ PDE3 } & F:5'-CCTGCAGAACCACAAGATGTGGAA-3' & $190 \mathrm{bp}$ \\
\hline & R:5'-TCACTGGTTTGGCTITGGTGTTGG-3' & \\
\hline
\end{tabular}

INSR, insulin receptor; IRS, insulin receptor substrate; PIP3, phosphatidylinositol 3-kinase; PDK1, 3-phosphoinositide-dependent protein kinase-1; Akt, protein kinase B; FOXO1, forkhead box protein O1; PDE3, cGMP-inhibited 3',5'-cyclic phosphodiesterase. 


\section{Results and discussion}

Animal fat sources such as beef tallow have low digestibility, which can be improved by mixing animal fat with various vegetable oils to increase meat quality via elevation of lipase activity [16-19]. Therefore, gene expression in the LM can be manipulated according to dietary nutrients.

DNA microarray analysis has previously revealed that dietary fat type influences LM gene expression profiles. In particular, expression of insulin signaling pathway-related genes has been shown to be significantly enriched in differential gene expression sets [6]. These changes also suggest significant changes in other insulin signaling pathway genes. Thus, we compared differential gene expression in the LM of three barrows and gilts for each dietary fat type. Various genes linked to insulin signaling pathway genes as well as differentially expressed genes identified through microarray analysis were confirmed by RT-PCR.

The insulin signaling pathway involves a number of genes that control glucose storage and uptake, protein synthesis, and regulation of lipid synthesis in pigs. Insulin inhibits lipid metabolism by activating a cAMP-specific phosphodiesterase in adipocytes, thereby reducing cellular cAMP concentrations [20]. As the insulin signaling pathway is closely related to fat metabolism [21], the seven genes were subjected to qRT-PCR to determine whether or not dietary fat type influences their expression in pigs. The seven genes were insulin receptor (INSR), insulin receptor substrate (IRS), phosphatidylinositol $(3,4,5)$-triphosphate (PIP3), 3phosphoinositide-dependent protein kinase-1 (PDK1), protein kinase B (Akt), forkhead box protein O1 (FOXO1), and cGMP-inhibited 3', 5'-cyclic phosphodiesterase (PDE3).

Expression levels of the seven DEGs were measured using the $\Delta \mathrm{Ct}$ method, and the results are shown in Tables 3 and 4. RT-PCR analysis determined the expression profiles of the insulin signaling pathway genes in growing-finishing pigs. In particular, the INSR, IRS, PIP3, and PDE3 genes showed significantly differential expression according to dietary oil composition in barrow pigs (Figure 1). INSR plays a key role in the regulation of glucose homeostasis, a functional process that may result in a range of clinical manifestations, including diabetes and cancer, under degenerate conditions [22]. IRS plays a key role in transmitting signals from insulin and insulin-like growth factor-1 (IGF-1) receptors to the intracellular Akt/PI3K and Erk/MAPK pathways [23]. PIP3 functions to activate downstream signaling components such as protein kinase Akt, which activates downstream anabolic signaling pathways required for cell growth and survival [24]. Especially, PDE3 undergoes phosphorylation and short-term activation in response to insulin as well as agents that increase cAMP in adipocytes, hepatocytes, and platelets [11].
Table 3 ANOVA table for each gene associated with feeding groups in barrows

\begin{tabular}{lllllll}
\hline Gene & Source & Df & Sum Sq & Mean Sq & F value & $\operatorname{Pr}(>\mathbf{F})$ \\
\hline INSR & Feed & 3 & 2.084 & 0.695 & 4.014 & $<0.05^{*}$ \\
& Residuals & 20 & 3.461 & 0.173 & & \\
IRS & Feed & 3 & 1.450 & 0.483 & 3.868 & $<0.05^{*}$ \\
& Residuals & 20 & 2.499 & 0.125 & & \\
PIP3 & Feed & 3 & 0.422 & 0.141 & 4.370 & $<0.05^{*}$ \\
& Residuals & 20 & 0.643 & 0.032 & & \\
PDK1 & Feed & 3 & 0.100 & 0.033 & 0.396 & 0.758 \\
& Residuals & 20 & 1.683 & 0.084 & & \\
Akt & Feed & 3 & 0.209 & 0.070 & 1.021 & 0.405 \\
& Residuals & 20 & 1.365 & 0.068 & & \\
FOXO1 & Feed & 3 & 1.527 & 0.509 & 1.880 & 0.166 \\
& Residuals & 20 & 5.416 & 0.271 & & \\
PDE3 & Feed & 3 & 0.927 & 0.309 & 5.213 & $<0.01^{* *}$ \\
& Residuals & 20 & 1.186 & 0.059 & & \\
\hline
\end{tabular}

INSR, insulin receptor; IRS, insulin receptor substrate; PIP3, phosphatidylinositol (3,4,5)-triphosphate; PDK1, 3-phosphoinositide-dependent protein kinase-1; Akt, protein kinase B; FOXO1, forkhead box protein O1; PDE3, cGMP-inhibited 3',5'-cyclic phosphodiesterase. ${ }^{*},{ }^{* *}$ Significant differences $(P<0.05$ and 0.01$)$ among the feeding groups determined using the mixed ANOVA module. DF = Degrees of freedom, Sum Sq = Sum of square, Mean Sq= Mean of square.

The INSR and IRS genes showed opposite gene expression patterns in barrows. Beef tallow was the only dietary fat source associated with low INSR expression as well as increased IRS expression. The PIP3 and PDE3 genes showed similar reduced expression levels in pigs

Table 4 ANOVA table for each gene associated with feeding groups in gilts

\begin{tabular}{|c|c|c|c|c|c|c|}
\hline Gene & Source & Df & Sum Sq & Mean Sq & F value & $\operatorname{Pr}(>F)$ \\
\hline \multirow[t]{2}{*}{ INSR } & Feed & 3 & 0.457 & 0.153 & 0.923 & 0.448 \\
\hline & Residuals & 20 & 3.304 & 0.165 & & \\
\hline \multirow[t]{2}{*}{ IRS } & Feed & 3 & 0.197 & 0.066 & 0.249 & 0.861 \\
\hline & Residuals & 20 & 5.268 & 0.263 & & \\
\hline \multirow[t]{2}{*}{ PIP3 } & Feed & 3 & 0.970 & 0.323 & 4.644 & $<0.05^{*}$ \\
\hline & Residuals & 20 & 1.393 & 0.070 & & \\
\hline \multirow[t]{2}{*}{ PDK1 } & Feed & 3 & 0.386 & 0.129 & 1.258 & 0.316 \\
\hline & Residuals & 20 & 2.043 & 0.102 & & \\
\hline \multirow[t]{2}{*}{ Akt } & Feed & 3 & 0.308 & 0.103 & 1.380 & 0.278 \\
\hline & Residuals & 20 & 1.486 & 0.074 & & \\
\hline \multirow[t]{2}{*}{ FOXO1 } & Feed & 3 & 2.712 & 0.904 & 7.830 & $<0.01^{* *}$ \\
\hline & Residuals & 20 & 2.309 & 0.115 & & \\
\hline \multirow[t]{2}{*}{ PDE3 } & Feed & 3 & 0.300 & 0.100 & 0.530 & 0.667 \\
\hline & Residuals & 20 & 3.770 & 0.189 & & \\
\hline
\end{tabular}

INSR, insulin receptor; IRS, insulin receptor substrate; PIP3, phosphatidylinositol (3,4,5)-triphosphate; PDK1, 3-phosphoinositide-dependent protein kinase-1; Akt, protein kinase B; FOXO1, forkhead box protein O1; PDE3, CGMP-inhibited $3^{\prime}, 5^{\prime}$-cyclic phosphodiesterase. ${ }^{*},{ }^{*}$ Significant differences $(P<0.05$ and 0.01$)$ among the feeding groups determined using the mixed ANOVA module. DF = Degrees of freedom, Sum Sq = Sum of square, Mean $\mathrm{Sq}=$ Mean of square. 

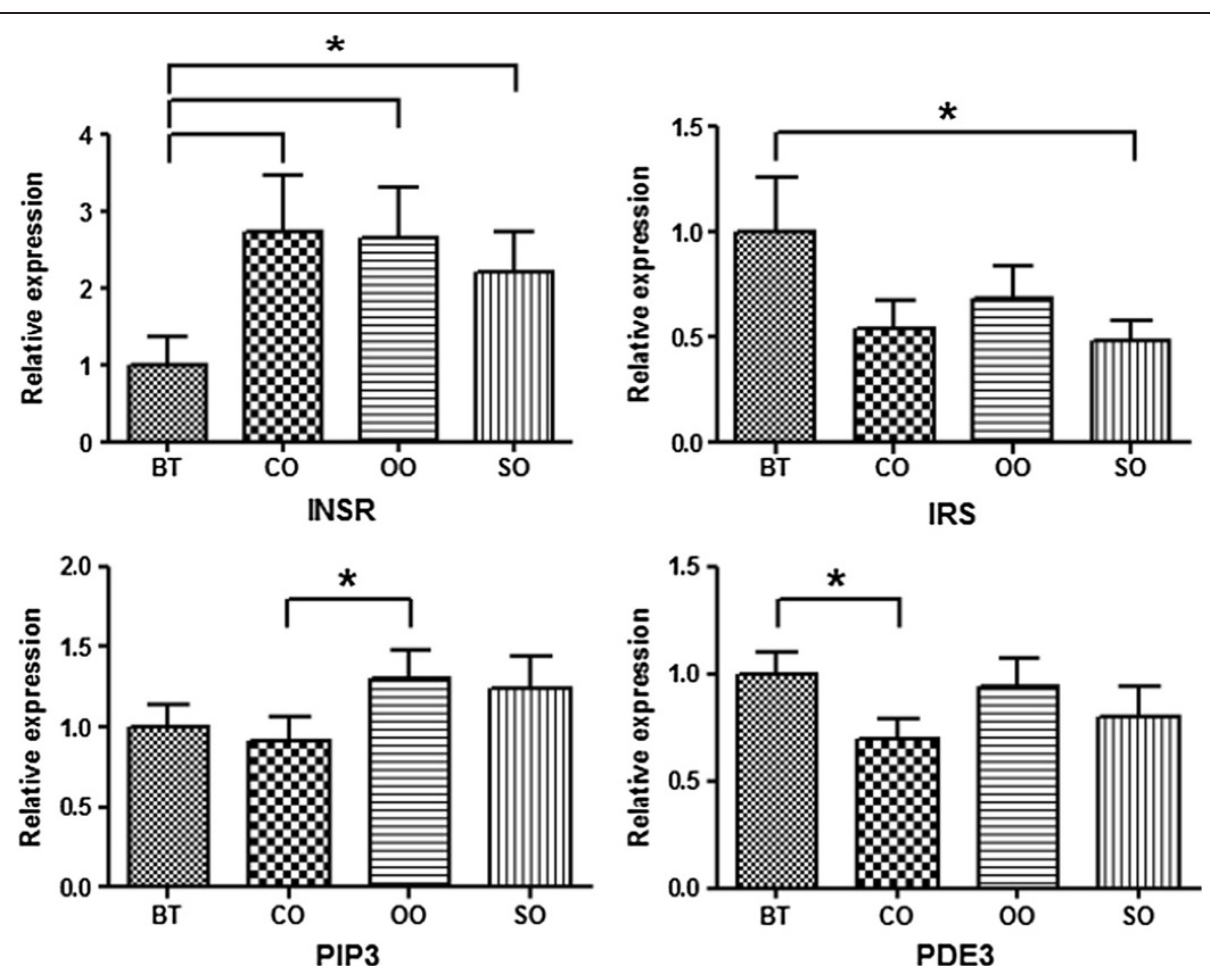

Figure 1 Expression patterns of differentially expressed genes in four dietary oil groups in barrows, as determined by qRT-PCR. Dietary fat sources were BT (beef tallow), CO (coconut oil), OO (olive oil), and SO (soybean oil), which were added at concentrations of $3.0 \%$ in feed. Experiments were performed using the LM from three barrows, and data are expressed as mean \pm SD. Asterisks show statistically significant values $(* P<0.05)$.

treated with coconut oil. In particular, INSR gene expression was up-regulated 2 -fold in pigs treated with other oils compared to beef tallow.

The PIP3 and FOXO1 genes showed significantly different expression levels among the four dietary oil groups in gilts (Figure 2). Specifically, the PIP3 and FOXO1 genes showed relatively high expression in gilts with coconut oil compared to other oils. Gene expression of FOXO1, which negatively regulates adipogenesis, was two times higher in gilts [25]. FOXO1 belongs to
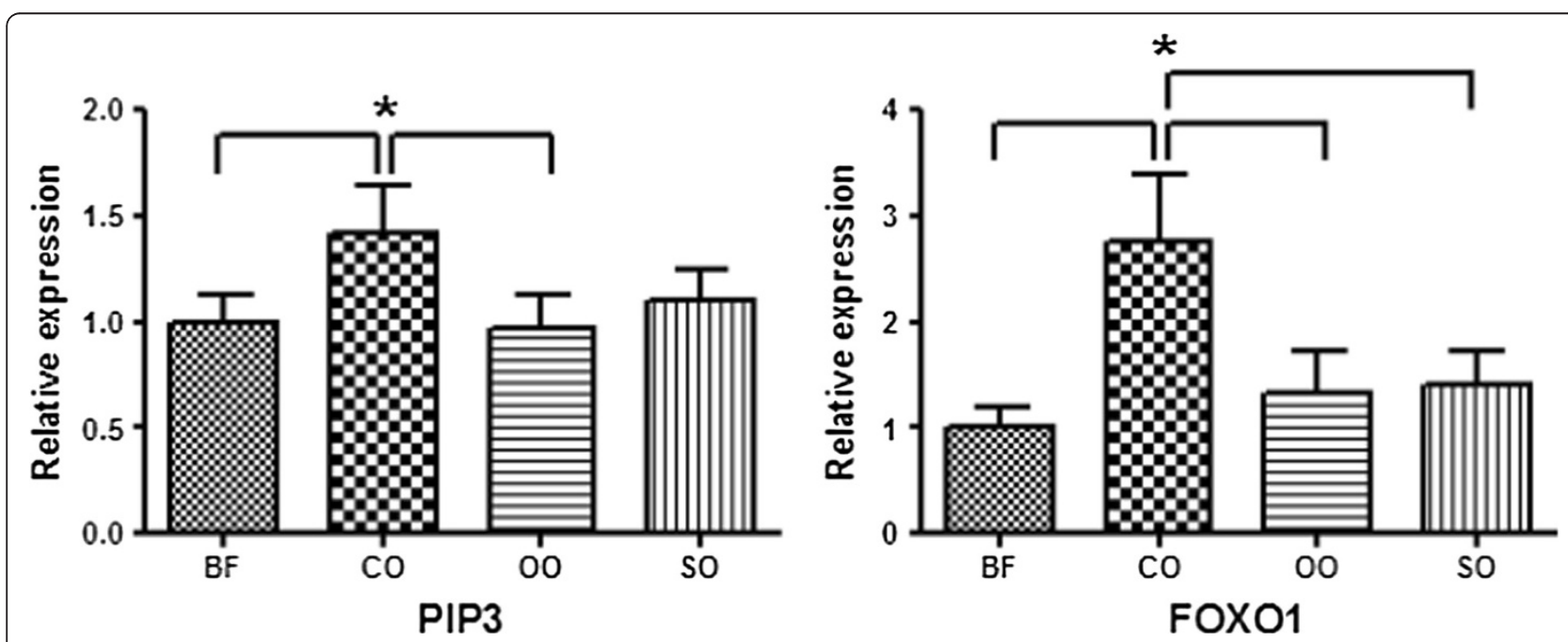

Figure 2 Expression patterns of differentially expressed genes in four dietary oil groups in gilts, as determined by qRT-PCR. Dietary fat sources were BT (beef tallow), CO (coconut oil), OO (olive oil), and SO (soybean oil), which were added to concentrations of $3.0 \%$ in feed. Experiments were performed using the LM from three gilts, and data are expressed as mean \pm SD. Asterisks show statistically significant values $\left({ }^{*} P<0.05\right)$ 
the forkhead family of transcription factors that increases transcription of glucose-6-phosphatase, resulting in elevated rates of gluconeogenesis and glycogenolysis [26]. Compared with other oils, activation of FOXO1 in pigs treated with coconut oil had a negative effect on intramuscular fat accumulation.

Barrows and gilts showed opposite patterns of PIP3 gene expression. These results show that dietary fat type affected patterns of gene expression according to animal gender. It is known that expression levels of genes are linked to gender differences and variations in fatty acids $[27,28]$. These results can be applied to livestock production by promoting the use of discriminatory feed supplies.

\section{Conclusion}

DNA microarray analysis has previously revealed that dietary fat type alters LM gene expression profiles. These changes also suggest significant changes in other insulin signaling pathway genes. Thus, we compared differential gene expression in the LM of three barrows and gilts for each dietary fat type. Various genes linked to insulin signaling pathway genes as well as differentially expressed genes identified through microarray analysis were confirmed by RT-PCR. Results show that seven genes (INSR, IRS, PIP3, PDK1, Akt, PDE3, and FOXO1) were located upstream of the insulin signaling pathway. In barrows, the INSR, IRS, PIP3, and PDE3 genes showed significantly differential expression according to dietary oil type. The PIP3 and FOXO1 genes showed significant differences in gene expression among the four dietary oil groups in gilts. In particular, barrow and gilt pigs showed opposite patterns of PIP3 expression. Therefore, dietary fat type affected patterns of gene expression by gender difference. These results can be applied to livestock production by promoting the use of discriminatory feed supplies.

\section{Competing interests}

The authors declare that they have no competing interests.

\section{Authors' contributions}

SCK, THK and BHC participated in the design of the study and total organization. SCK and HCJ made the laboratory work. SDL and HJJ made feeding and animal management work. JCP made sampling work. SHL performed the statistical analysis. All authors helped to draft the manuscript, and all authors read and approved the final manuscript.

\section{Acknowledgements}

This study was supported by the Agenda (PJ0087112013) and 2013 PostDoctoral Fellowship Program of National Institute of Animal Science, Rural Development Administration, Republic of Korea.

\section{Author details}

${ }^{1}$ Animal Genomics \& Bioinformatics Division, National Institute of Animal Science, Rural Development Administration, Chuksan-gil 77, Kwonsun-gu, Suwon, Korea. ${ }^{2}$ Swine Science Division, National Institute of Animal Science, Rural Development Administration, Cheon-an, Chungnam 330-801, Korea.
Received: 28 July 2014 Accepted: 28 July 2014

Published: 1 August 2014

\section{References}

1. Cera KR, Mahan DC, Reinhart GA: Effects of dietary dried whey and corn oil on weanling pig performance, fat digestibility and nitrogen utilization. J Anim Sci 1988, 66:1438-1445

2. Howard KA, Forsyth DM, Cline TR: The effect of an adaptation period to soybean oil additions in the diets of young pigs. J Anim Sci 1990, 68:678-683.

3. Li DF, Thaler RC, Nelssen JL, Harmon DL, Allee GL, Weeden TL: Effect of fat sources and combinations on starter pig performance, nutrient digestibility and intestinal morphology. J Anim Sci 1990, 68:3694-3704.

4. Overland M, Tokach MD, Cornelius SG, Pettigrew JE, Rust JW: Lecithin in swine diets: I. Weanling pigs. J Anim Sci 1993, 71:1187-1193.

5. Tokach MD, Pettigrew JE, Johnston L, Overland M, Rust JW, Cornelius SG: Effect of adding fat and(or) milk products to the weanling pig diet on performance in the nursery and subsequent grow-finish stages. J Anim Sci 1995, 73:3358-3368.

6. Park JC, Kim SC, Lee SD, Jang HC, Kim NK, Lee SH, Jung HJ, Kim IC, Seong $\mathrm{HH}$, Choi BH: Effects of dietary fat types on growth performance, pork quality, and gene expression in growing-finishing pigs. Asian-Aust J Anim Sci 2012, 25:1759-1767.

7. Yin J, Li D: Nutrigenomics Approach - A strategy for identification of nutrition responsive genes influencing meat edible quality traits in swine. Asian-Aust J Anim Sci 2009, 22:605-610.

8. Saltiel AR, Kahn CR: Insulin signalling and the regulation of glucose and lipid metabolism. Nature 2001, 414:799-806.

9. Fritsche L, Weigert $\mathrm{C}$, Haring $\mathrm{H}-\mathrm{U}$, Lehmann R: How insulin receptor substrate proteins regulate the metabolic capacity of the liverimplications for health and disease. Curr Med Chem 2008, 15:1316-1329.

10. Izuchi R, Nakai Y, Takahashi H, Ushiama S, Okada S, Misaka T, Abe K: Hepatic gene expression of the insulin signaling pathway is altered by administration of persimmon peel extract: a DNA microarray study using type 2 diabetic goto-kakizaki rats. J Agric Food Chem 2011, 59:3320-3329.

11. Degerman E, Belfrage P, Manganiello VC: Structure, Localization, and Regulation of cGMP-inhibited Phosphodiesterase (PDE3). J Biol Chem 1997, 272:6823-6826.

12. Maurice DH, Palmer D, Tilley DG, Dunkerley HA, Netherton SJ, Raymond DR, Elbatarny HS, Jimmo SL: Cyclic nucleotide phosphodiesterase activity, expression, and targeting in cells of the cardiovascular system. $\mathrm{Mol}$ Pharmacol 2003, 64:533-546.

13. Daitoku H, Fukamizu A: FOXO transcription factors in the regulatory networks of longevity. J Biochem (Tokyo) 2007, 141:769-774.

14. Huang $T$, Xiong Y-Z, Lei M-G, Xu D-Q, Deng C-Y: Identification of a Differentially Expressed Gene PPP1CB between Porcine Longissimus dorsi of Meishan and Large Whitex Meishan Hybrids. Acta Biochim Biophys $\operatorname{Sin}$ 2006, 38:450-456

15. Cohen PTW: Novel protein serine/threonine phosphatases: Variety is the spice of life. Trends Biochem Sci 1997, 22:245-251.

16. Powles J, Wiseman J, Cole DJA, Hardy B: Effect of chemical structure of fats upon their apparent digestible energy value when given to growing/finishing pigs. Ani Sci 1993, 57:137-146.

17. Powles J, Wiseman J, Cole DJA, Hardy B: Effect of chemical structure of fats upon their apparent digestible energy value when given to young pigs. Ani Sci 1994, 58:411-417.

18. Mountzouris KC, Fegeros K, Papadopoulos G: Utilization of fats based on the composition of sow milk fat in the diet of weanling pigs. Anim Feed Sci Technol 1999, 77:115-124

19. Cho JH, Kim HJ, Chen YJ, Yoo JS, Min BJ, Kim JD, Kim IH: the effect of soybean oil, tallow and coconut oil supplementation on growth performance, serum lipid changes and nutrient digestibility in weaned pigs. J Anim Sci Technol 2007, 49:33-40.

20. Kitamura T, Kitamura Y, Kuroda S, Hino Y, Ando M, Kotani K, Konishi H, Matsuzaki H, Kikkawa U, Ogawa W, Kasuga M: Insulin-induced phosphorylation and activation of cyclic nucleotide phosphodiesterase 3b by the serine-threonine kinase akt. Mol Cell Biol 1999, 19:6286-6296.

21. Wong RHF, Sul HS: Insulin signaling in fatty acid and fat synthesis: a transcriptional perspective. Curr Opin Pharmacol 2010, 10:684-691.

22. Ward CW, Lawrence MC: Ligand-induced activation of the insulin receptor: a multi-step process involving structural changes in both the ligand and the receptor. BioEssays 2009, 31:422-434. 
23. Sun X, Rothenberg P, Kahn C, Backer J, Araki E, Wilden P, Cahill D, Goldstein $B$, White M: Structure of the insulin receptor substrate IRS-1 defines a unique signal transduction protein. Nature 1991, 352:73-77.

24. Whitman M, Downes CP, Keeler M, Keller T, Cantley L: Type I phosphatidylinositol kinase makes a novel inositol phospholipid, phosphatidylinositol-3-phosphate. Nature 1988, 332:644-646.

25. Farmer SR: The Forkhead Transcription Factor Foxo1: A Possible Link between Obesity and Insulin Resistance. Mol Cell 2003, 11:6-8.

26. Nakae J, Kitamura T, Silver DL, Accili D: The forkhead transcription factor Foxo1 (Fkhr) confers insulin sensitivity onto glucose-6-phosphatase expression. J Clin Invest 2001, 108:1359-1367.

27. Zhang S, Knight TJ, Stalder K, Goodwin RN, Lonergan SM, Beitz DC: Effects of breed, sex, and halothane genotype on fatty acid composition of pork longissimus muscle. J Anim Sci 2007, 85:583-591.

28. Miersch C, Doring F: Sex differences in carbohydrate metabolism are linked to gene expression in Caenorhabditis elegans. PLoS One 2012, 7:e44748.

doi:10.1186/2055-0391-56-12

Cite this article as: Kim et al:: Changes in expression of insulin signaling pathway genes by dietary fat source in growing-finishing pigs. Journal of Animal Science and Technology 2014 56:12.

\section{Submit your next manuscript to BioMed Central and take full advantage of:}

- Convenient online submission

- Thorough peer review

- No space constraints or color figure charges

- Immediate publication on acceptance

- Inclusion in PubMed, CAS, Scopus and Google Scholar

- Research which is freely available for redistribution 